\title{
Synchronous Primary Ovarian and Endometrial Carcinomas in a Young Patient Case report and literature review
}

\author{
CIPRIAN LAURENTIU PATRU ${ }^{1 \#, ~ M A R I U S ~ C R I S T I A N ~ M A R I N A S ~}{ }^{* * \#, ~ I L E A N A ~ D R O C A S ~}{ }^{1}$, \\ FLORENTINA TANASE ${ }^{1}$, TIBERIU STEFANITA TENEA COJAN ${ }^{3 \#}$, GABRIEL FLORIN RAZVAN MOGOS ${ }^{3 \#,}$ \\ ANA MARIA IFRIM PREDOI ${ }^{3}$, VLAD DUMITRU BALEANU ${ }^{4 \#, ~ D R A G O S ~ V I R G I L ~ D A V I T O I U ~}{ }^{5 \#, ~}$ \\ RAZVAN-GRIGORAS CAPITANESCU ${ }^{1 \#}$ \\ ${ }^{1}$ University of Medicine and Pharmacy of Craiova, Obstetrics and Gynecology Department, 2 Petru Rares Str., 200349, \\ Craiova, Romania \\ ${ }^{2}$ University of Medicine and Pharmacy of Craiova, Anatomy Department, 2 Petru Rares Str., 200349, Craiova, Romania \\ ${ }^{3}$ University of Medicine and Pharmacy of Craiova, General Surgery Department, 2 Petru Rares Str., 200349, Craiova, \\ Romania \\ ${ }^{4}$ University of Medicine and Pharmacy of Craiova, Surgery Department, Clinical Emergency Hospital St. Pantelimon, \\ 340-342 Pantelimon Road, 021659, Bucharest, Romania \\ ${ }^{5}$ University of Medicine and Pharmacy of Bucharest, Surgery Department, Clinical Emergency Hospital Sf. Pantelimon, \\ 340-342 Pantelimon Road, 021659, Bucharest, Romania
}

Synchronous primary ovarian and endometrial carcinomas is a rare condition encountured in clinical practice, especially in young patients with history of endometriosis. The most frequent histopatological subtype is endometrioid carcinoma. We present a case of a 36-years old patient admitted in the Emergency Department for lower abdominal pain and abnormal uterine bleeding. The clinical and ultrasound examination diagnosed bilateral ovarian cystic tumors, a normal uterine structure and no abdominal fluid colection. Serum levels of ROMA score was performed with normal value. The International Ovarian Tumor Analysis (IOTA) criteria used for ovarian tumors scoring diagnosed a 55\% probability for malignant tumors. Laparotomy was performed with prelevation of peritoneal fluid for citology. After right anexectomy was performed, the intraoperative histopathological examination diagnosed endometrioid ovarian carcinoma. Left anexectomy and total hysterectomy with omentectomy and multiple peritoneal biopsy was further performed. The final histopathological examination confirmed endometroid carcinoma in both ovaries and endometrial tissue.

Keywords: synchronous genital carcinomas, endometrioid subtype, endometriosis

Recent literature shows that synchronous primary ovarian and endometrial carcinoma is the most frequent encountered diagnosis in case of synchronous reproductive genital tumours. Coexisting carcinomas of the endometrium and ovaries were described in $10 \%$ of the ovarian and 5\% of the endometrial tumors [1-3], the endometrioid carcinoma being most frequently reported.

Patients with synchronous primary disease have better prognosis compared with patients with single disease and associated metastasis. The diagnostic accuracy in case of synchronous primary genital tumours is very important because it changes the treatment care [4-7].

Since 1985, Woodruff et al [8] defined that two or more primary tumors that occur closely in time in a patient are termed as synchronous tumors and they can arise in the same or different site with different morphologies or in different sites with the same morphology.

Zaino et al [1] described that synchronous genital carcinomas were misdiagnosed as FIGO stage III - endometrial carcinoma or FIGO stage II - ovarian carcinoma.

Immunohistochemistry and DNA flow cytometry were used for the distinction of primary tumours with the same histologic type. The histopathological criteria described by Scully et al [9] were used to differentiate between independent primary cancers and single malignant tumors associated with metastasis (Table 1). 
Table 1

ENDOMETRIOID TUMORS OF THE OVARY AND ENDOMETRIUM

\begin{tabular}{|l|l|}
\hline 1 & Histological dissimilarity of the tumors \\
\hline 2 & No or only superficial myometrial invasion of the endometrial tumor \\
\hline 3 & No vascular space invasion of the endometrial tumor \\
\hline 4 & Atypical endometrial hyperplasia (additionally present) \\
\hline 5 & Absence of other evidence of spread of the endometrial tumor \\
\hline 6 & Ovarian unilateral tumor ( $80-90 \%$ of cases) \\
\hline 7 & Ovarian tumor located in the parenchyma \\
\hline 8 & No vascular space invasion, surface implants or predominant hilar ovarian location \\
\hline 9 & No evidence of spread of the ovarian tumor \\
\hline 10 & The presence of ovarian endometriosis \\
\hline 11 & Different ploidy of DNA indices \\
\hline 12 & Dissimilar molecular genetic or karyotypic abnormalities in the tumors \\
\hline
\end{tabular}

\section{Experimental part}

This paper reports a case of a 36 years old patient hospitalized in the Obstetrics and Gynecology Department, Emergency County Hospital from Craiova, for pelvic pain and abnormal uterine bleeding. Seven years before being admitted to the hospital the pacient had a caesarean section delivery for a macrosome fetus.

The clinical gynecological examination revealed a normal uterine cervix with minimal vaginal bleeding, a retroverted position of the uterus with normal diameter, regulate surface and normal consistence. We diagnosed moderate pain to compression and mobilisation of the uterus, a bilateral anexial tumor, with elastic consistence and intense pain. The transvaginal ultrasound examination confirmed bilateral ovarian tumors (Fig 1).

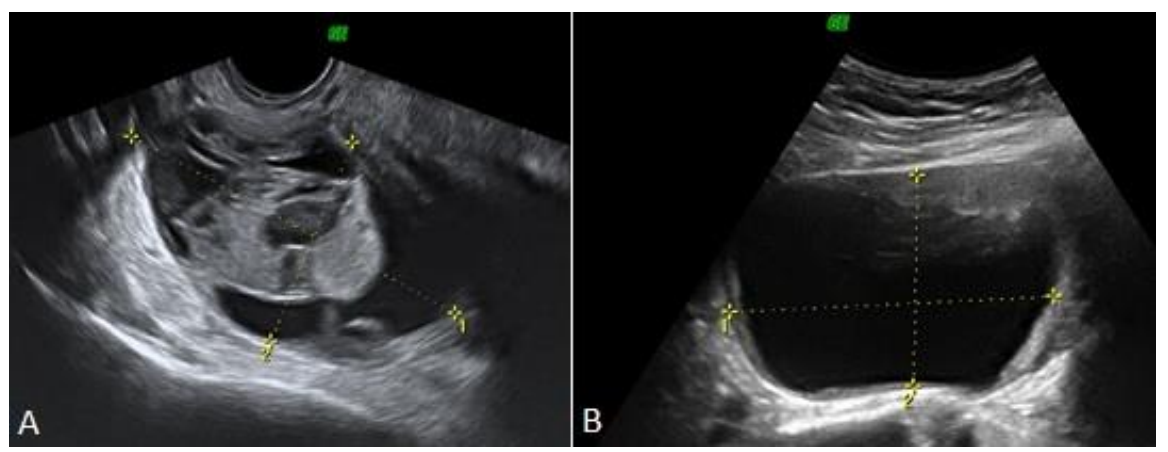

Fig 1. A-Right ovarian tumor with solid and liquidian content. B-Left ovarian tumor with liquidian content

Biological blood samples and thoracic X-ray were normal. We performed specific ovarian tumor markers CA125, HE4, $\beta$-HCG, CA15-3, CA19-9 and CEA with normal values.

Computer Tomography (CT) with contrast substance was performed. This investigation diagnosed 2 heterogenous masses of $8 / 6 \mathrm{~cm}$ and 7,4/6,6 cm with fluid density and high marginal captation, the uterus with heterogenous captation and no lymphatic invasion.

Laparotomy was performed. Peritoneal fluid sample for citology was prelevated and right anexectomy was performed. The intraoperative hystopathological examination diagnosed endometrioid ovarian carcinoma. Left anexectomy and total hysterectomy with infracolic omentectomy and multiple peritoneal biopsy was further performed. The hystopathological examination confirmed endometroid carcinoma in both ovarian and endometrial tissue.

There were no postoperative complications and the patient was discharged on day 6 . On endometrial probes, the final pathological reports described well diferentiated (G1) endometrioid carcinoma with $1 / 2$ myometrial invasion (Fig 2). Moderate well diferentiated (G2) endometrioid carcinoma was also described on the ovarian probes (Fig 3 and Fig 4). Peritoneum and omentum biopsy samples were normal. The patient was referred to Oncology Department for specific treatment. 


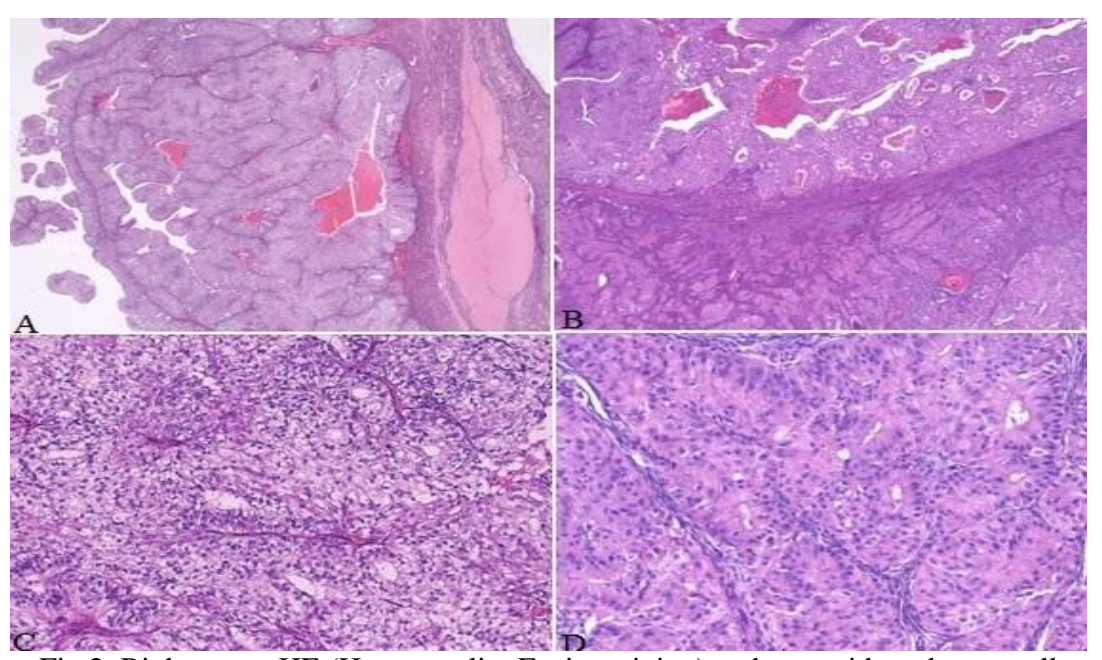

Fig 2. Right ovary-HE (Hematoxylin-Eosin staining) endometroid moderate well

differentiated carcinoma: A) secretory type, HE staining x2.0; B) areas of scuamous metaplasia,

HE staining x2.5; C) secretory type, HE staining x20 ; D) areas of scuamous metaplasia, HE staining x2.5

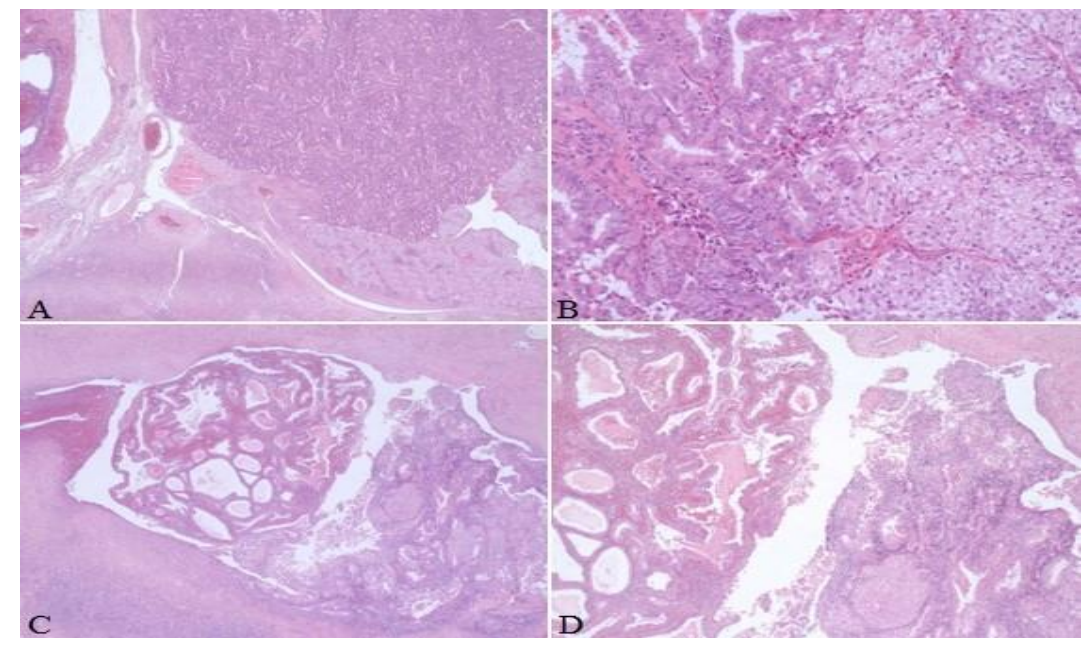

Fig 3. Left ovary-HE (Hematoxylin-Eosin staining) endometroid moderate well differentiated carcinoma:

A) secretory type, HE staining x2.5; B) secretory type, HE stainig x20; C) areas of endometriosis,

B) HE staining $\mathrm{x} 2.5$; D) areas of endometriosis, HE staining $\times 2.5$

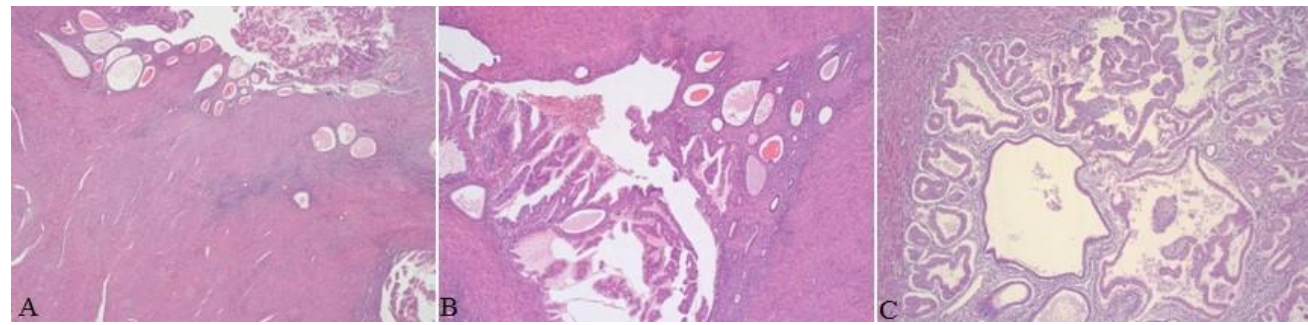

Fig 4. Uterus-HE (Hematoxylin-Eosin staining) endometrioid well differentiated adenocarcinoma:

A) $1 / 2$ myometrial invasion and area of endometriosis, HE staining $\times 2.5 \mathrm{~B}$ );

B) $1 / 2$ myometrial invasion and area of endometriosis, HE staining x 5; C) HE staining x5.

\section{Results and discussions}

In our case presentation the diagnosis of synchronous primary endometrial and ovarian cancer was made in a young patient. Most studies reported this condition in postmenopausal woman [2,3]. Other authors concluded that patients who develop synchronous primary endometrial and ovarian cancer are younger than patients who develop only endometrial or ovarian cancer [10], and the signs or symptoms are similar to independent endometrial or ovarian cancer.

The most common symptoms are abnormal uterine bleeding (65\%), the presence of abdominal masses (26\%) and abdominal pain (40\%). In our case we found similar symptoms. Eifel et al. [11] reported a mean age of 41 years old at diagnosis of the endometrioid cancer, in contrast with Gynecologic Oncology Group who reported a mean age of 49 years old [1].

Studies examining young females (age less than 45 years) diagnosed with endometrial cancer, reported that 10-29\% were diagnosed with synchronous ovarian cancers. [12,13]. 
Eifel et al. [11] concluded that the role of estrogen in case of synchronous genital cancer should be furder evaluated and the response of the uterine corpus, fallopian tubes and ovarian epithelium as a morphologic unit could explain the development of synchronous endometrioid tumors in different components of the mullerian system.

In our case, the final histological probes confirmed ovarian endometriosis. This disease is sustained by other authors as a high-risk factor for ovarian epitelial cancer [14-16]. Accordind to Kurman [17] carcinomas associated with endometriosis are mostly located at the ovarian sites. He described that the most frequent histological type associated with endometriosis is the clear cell endometrioid carcinoma. Same authors [17] described a dualist pathway for epithelial ovarian cancer and divided tumors in two groups: Tip I (low-grade tumors) and Tip II (high-grade tumors) (Table 2).

Table 2

PATHWAY FOR EPITHELIAL OVARIAN CANCER DESCRIBED BY KURMAN

\begin{tabular}{|c|c|}
\hline Tip I (low-grade tumors) & TIP II (high-grade tumors) \\
\hline Low-grade serous & High-grade serous \\
\hline Low-grade endometrioid & Low-grade endometrioid \\
\hline Clear cells & Malignant mixed mesodermal \\
\hline Mucinous carcinomas & Undifferentiated carcinomas \\
\hline
\end{tabular}

Many authors [18-20] described that the mutation in ARID1A or loss of BAF250a expression are the most encountered genetic disorders asociated with endometriosis. They concluded that this condition is more frequent in clear cell carcinomas than epitelial ovarian carcinomas. Mingels et al [21] analized histological samples from 186 pacients diagnosed with epithelial ovarian cancer and discovered high prevalence of atypical hyperplasia in the endometrium, and reports in 81 pacients(44\%) endometrial lesion who was premalignant in $58(31 \%)$ pacients and malignant in 6(3\%), primary endometrial carcinoma. Same authors reported a higer body mass index (BMI) in pacients with atypical endometrial hyperplasia in comparation in pacients with normal endometrium, and performed genetical tests who described BRCA mutation carriers in both groups.

In this study we didn't performed imunohistochemical analysys but the previous study remarks that the immunexpression of EGFR, HER 2-neu and ki 67 was correlated with tumor type and grade differentiation and no association with the clinical parameters [22].

Regarding the immunexpresion of p53 and p16, Marinaș et.al [20] reported in a series of 24 selected ovarian tumors, that p53 immunostaining was present in all borderline tumors and 85\% of carcinomas, the highest PI being observed in high-grade carcinomas; p16 immunexpresion was identified in $75 \%$ of malignant and borderline tumors. He concluded that the stain had the highest values in high-grade carcinomas and borderline tumors.

In females diagnosed with EOC (endometrial ovarian cancer), the presence of concomitant endometrial premalignancy has to be taken into account. Most likely, concurrent atypical hyperplasia represents a premalignant stage of synchronous endometrioid carcinoma [23].

Conservative surgery can be performed in patients diagnosed in the early stages of endometrial ovarian cancer (EOC), sparing the contralateral ovary and uterus [24-26].

Surgical treatment is the main treatment for endometrial and ovarian cancers. The intervention involves hysterectomy, bilateral salpingo-oophorectomy, omentectomy and appedenctomy [27,28].

Ayhan et al concluded that the stage of the ovarian cancer and the grade of the endometrial cancer are important prognostic factors $[29,30]$.

Some authors argue the use of combined hormonal contraception in females with endometriosis as a chemopreventive factor against gynaecological synchronous malignancies [31-35].

Gungor et al [36] reported that ovarian and endometrial synchronous cancers were the most frequent synchronous cancers with a 77\% survival rate in 21 patients diagnosed with synchronous gynaecological cancers.

Synchronous tumours of the ovary and endometrium have good prognosis especially in the early stages. The survival rates at 5 and 10 years are $86 \%$ and $80 \%$. They depend on the FIGO stage, tumor histology and treatment strategies [3740].

\section{Conclusions}

It is difficult to diagnose synchronous primary ovarian and endometrial cancers before surgery. This condition is rare but the diagnosis should be taken into consideration in case of abnormal uterine bleeding associated with ovarian tumors.

In early stages, the prognosis of synchronous primary ovarian and endometrial cancers is significantly improved compared to metastatic disease. For the metastatic group there is a higher recurrence risk and frequently, the adjuvant therapy is needed. 


\section{References}

1.ZAINO, R., WHITNEY, C., BRADY, M., DEGEEST, K., BURGER, R.A., BULLER. R.E. Simultaneously detected endometrial and ovarian carcinoma - a prospective clinicopathologic study of 74 cases: a gynecologic oncology group study. Gynecol Oncol. 2001 Nov, 83 (2), p 355-62.

2. SOLIMAN, P.T., SLOMAVITZ, B., BROADDUS, R., SUN, C.C., OH, J.C., EIFEL, P.J., GERSHENSON, D.M., LU, K.H. Synchronous primary cancers of the endometrium and ovary: a single institution review of 84 cases. Gynecol Oncol. 2004 Aug. 94 (2). p456-62.

3. LOU, H.M., LOU, H.K., WU, M.J. Synchronous primary cancerof the endometrium and ovary. Chin J Oncol. 2006 Aug. 28 (8). p.617-20.

4. CHIANG, Y.C., CHEN, C.A., HUANG, C.Y., HSIEH, C.Y., CHENG, W.F. Synchronous primary cancers of the endometrium and ovary.Int J Gynecol Cancer, 2008, 18 (1), p. 159-64.

5. Woodruff, J.D., Solomon, D., Sullivant, H,. Multifocal disease in the upper genital canal. Obstet Gynecol, 1985, 65 (5), p.695-8.

6. LUCRETIU, R, CARSOTE, M, PREDESCU, AM, TENEA COJAN, TS, SOCEA, B, BALEANU, VD, POPESCU, M, IONOVICI, N, ALBULESCU, DM. Rev. Chim. (Bucharest), 69, no. 12, 2018. p.3483-3485.

7. TENEA COJAN, TS, RADU, L, DAVITOIU, D, VLADU, IM, BALEANU, VD, CLENCIU, D, ENE, CG, SOCEA, B. Rev. Chim. (Bucharest), 69, no.10, 2018. p.2677-2681.

8. ENE, CG, MITROI, M, VLADU, IM, RADU, M, TENEA COJAN, TS, PREDESCU, AM, BUNESCU, MG. Rev. Chim. (Bucharest), 70, no.6, 2019. p.2108-2111.

9. SCULLY, R.E., YOUNG, R.H., CLEMENT. P.B., Tumors of the ovary, maldeveloped gonads, fallopian tube and broad ligament. Atlas of tumor pathology. Bethesda, MD: Armed Forces Institute of Pathology, 1998.

10. WILLIAMS, M.G., BANDERA, E.V., DEMISSIE, K., RODRÍGUEZ-RODRÍGUEZL. Synchronous primary ovarian and endometrial cancers. A population-based assessment of survival. Obstet Gynecol., 113, no.4, 2009. p.783-9.

11. EIFEL, P., HENDRICKSON, M., ROSS, J. BALLON, S., MARTINEZ, A., KEMPSON, R. Simultaneous presentation of carcinoma involving the ovary and the uterine corpus. Cancer. 50, no.1, 1982. p.163-70.

12. YAMAZAWA, K., SEKI, K., MATSUI, H., KIHARA, M., SEKIYA, S. Prognostic factors in young women with endometrial carcinoma: a report of 20 cases and a review of the literature. Int J Gynecol Cancer. $2000 ; \mathbf{1 0}(3)$, p.212-22.

13. EVANS-METCALF, E.R., BROOKS, S.E., REALE, F.R., BAKER, S.P. Profile of women 45 years of age and younger with endometrial cancer. Obstet Gynecol. 1998, 91(3). p.349-54.

14. KOBAYASHI, H., SUMIMOTO, K., MONIWA, N., ARISAWA, K., TERAO, T. Risk of developing ovarian cancer among women with ovarian endometrioma: a cohort study in Shizuoka, Japan. Int J Gynecol Cancer. 17(1). 2007. p.37-43.

15. KIM, H.S., KIM, T.H., CHUNG, H.H., SONG, Y.S. Risk and prognosis of ovarian cancer in women with endometriosis: a metaanalysis. Br J Cancer. 110(7), 2014. p.1878-90.

16. SARASWAT, L., AYANSinA, D., COOPER, K.G., BHATTACHARYA, S., HORNE, A.W., BHATTACHARYA, S. Impact of endometriosis on risk of further gynaecological surgery and cancer: a national cohort study. BJOG . Jan;125(1), 2018. p.64-72.

17. KURMAN R,J, SHIH, IEM. The dualistic model of ovarian carcinogenesis: revisited, revised, and expanded. Am J Pathol. 2016 Apr;186(4):733-47.

18. SCARFONE, G, BERGAMINI, A, NOLI, S, VILLA, A, CIPRIANI, S, TACCAGNI, G, VIGANO, P, CANDIAMI, M, PARAZZINI, F, MANGILI, G. Characteristics of clear cell ovarian cancer arising from endometriosis: a two center cohort study. Gynecol Oncol. 2014;133(3):4804.

19. AYHAN, A, MAO, T,L, SECKIN, T, WU, C,H, GUAN, B, OGAWA, H, FUTAGAMI, M, MIZUKAMI, H, YOKOYAMA, Y, KURMAN, $\mathrm{R}, \mathrm{J}, \mathrm{SHIH}, \mathrm{LEM}$. Loss of ARID1A expression is an early molecular event in tumor progression from ovarian endometriotic cyst to clear cell and endometrioid carcinoma. Int J Gynecol Cancer. 2012; 22(8):1310-5.

20. STAMP, J,P, GILKS, C,B, WESSELING, M, ESHRAGH, S, CEBALLOS, K, ANGLESIO, M,S, KWON, J,S, TONE, A, HUNTSMAN, D, G, CAREY, M,S. BAF250a Expression in atypical endometriosis and endometriosis-associated ovarian cancer. Int J Gynecol Cancer.2016; 26(5):825-32.

21. MINGELS, M,J, MASADAH, R, GEELS, Y,P, OTTE-HÖLLER, I, DE KIEVIT, I,M, VAN DER LAAK, J,A, VAN HAM, M,A, BULTEN, J, MASSUGER, L,F.High prevalence of atypical hyperplazia in the endometrium of patients with epithelial ovarian cancer.Am J Clin Pathol. 2014 Aug; 142(2):213-21.

22. MARINAŞ, M,C, MOGOŞ, G, CIUREA, R, MOGOŞ, D,G. EGFR, HER2/neu and Ki67 immunoexpression in serous ovarian tumors. Rom J Morphol Embryol. 2012; 53(3):563-567.

23. MARINAŞ, MC, MOGOŞ, DG, SIMIONESCU, CE, STEPAN, A, TĂNASE, F. The study of p53 and p16 immunoexpression in serous borderline and malignant ovarian tumors Rom J Morphol Embryol. 2012; 53(4):1021-1025.

24. TAFE, LJ, RIGGS, ER, TSONGALIS, GJ. Lynch syndrome presenting as endometrial cancer. Clin Chem.2014; 60(1):111-121.

25. ESKANDER, RN, RANDALL, LM, BERMAN, ML, TEWARI, KS, DISAIA, PJ, BRISTOW, RE. Fertility preserving options in patients with gynecologic malignancies. Am J Obstet Gynecol. 2011; 205(2):103-110.

26. VILCEA, ID, VASILE, I, TOMESCU, P, et al, "Loco-regional advanced colorectal cancer: diagnostic and therapeutic features", Chirurgia, vol 103, Issue2, Pg 189-194, Mar-Apr 2008;

27. COJAN, T.S. TENEA, VIDRIGHIN, C, CIOBANU , M, et al "Breast-conserving surgery in breast cancer", Chirurgia, vol 107, issue 5, pg 616-625, sept-oct 2012.

28. VASILE, I, MIREA, C, VILCEA, ID, et al "Esophago-digestive anastomosis dehiscence", Chirurgia, Vol 104, Issue 3, pg $281-286,2009$.

29. CORICI OM, TANASIE, CA, ALEXANDRU, DO, "A morpho-functional study using PEP/LVET ratio and global longitudinal strain in patients with dilated cardiomyopathy", Romanian Journal of Morphology and Embryology, Vol 59, Issue 1, pg 93-103, 2018.

30. SIGNORELLI, M, FRUSCIO, R, LISSONI, AA, PIROVANO, C, PEREGO, P, MANGIONI, C. Synchronous early-stage endometrial and ovarian cancer. Int J Gynaecol Obstet.2008; 102(1). p.34-38.

31. AYHAN, A, GUVENAL, T, COSKUN, F, BASARAN, M, SALMAN, MC. Survival and prognostic factors in patients with synchronous ovarian and endometrial cancers and endometrial cancer mestastatic to the ovaries. Eur J Gynaecol Oncol.2003; 24(2): 171-174.

32. NEDELCUTA, RM, CALIN, G, BALEANU, VD, DAVITOIU, DV, VOICULESCU, DI, MIREA, CS, TENEA COJAN, TS, SOCEA, B, ALEXANDRU, DO, CLENCIU, D, GHEORMAN, V, UDRISTOIU, I, CALBOREAN, V, CIORA, CA. Rev. Chim. (Bucharest), 70, no. 5, 2019, p. 1698-1702.

33. STANESCU, GL, NEDElCUTA, RM, DOP, D, DIACONU, R, CALIN, G, NICULESCU, EC, GHEONEA, C, STANESCU, R, ANGHELINA, L, STANESCU, MR. Brain abscess of unknown etiology in a 2-year-old child: a case report. Rom J Morphol Embryol 2015, 56(3). p. 1201-1204. 
34. CLENCIU, D, TENEA COJAN, TS, DIJMARESCU, AL, ENE, CG, DAVITOIU, DV, BALEANU, VD, CIORA, CA, SOCEA, B, VOICULESCU, DI, NEDELCUTA RM, CALBOREAN, V, GHEORMAN, V, VLADU,IM. Rev.Chim. (Bucharest), 70, no.4, 2019, p. 1434-1438. 35. KAUNITZ, AM. Oral contraceptives and gynecologic cancer: an update for the 1990s. Am J Obstet Gynecol.1992; 167 (Pt 2):1171-6.

36. GUNGOR, T, PEKTAS, MK, USTUNYURT, E, MOLLAMAHMUTOGLU, L. Synchronous primary tumors of the female genital tract: a single center experience. Arch Gynecol Obstet. 279(5), 2009. p.667-72.

37. NEDELCUTA, R, BALEANU, VD, CIORA, C, CALIN, G, STANESCU, MR, DAVITOIU, DV, TENEA COJAN, TS, SOCEA, B, VOICULESCU, DI, ALEXANDRU, DO, STANESCU, R. Rev. Chim. (Bucharest), 70, no.5, 2019, p. 1859-1862.

38. GHEORMAN, V, DINESCU, VC, CRICIOTOIU, O, STANCA, D, CALBOREAN, V, MITA, A, MISCOCI, A, DAVITOIU, DV, BALEANU, VD, NEDELCUTA, RM, DINESCU, SN, DIJMARESCU, AL, VOICULESCU, DI, UDRISTOIU, I. Rev. Chim. (Bucharest), 70, no. 4, 2019, p. 1406-1410.

39. NEDELCUTA, R, POPESCU, M, CALIN, G. Digestive Manifestations in Wilms' Tumor. NEUROGASTRO 2017 - MEETING OF THE ROMANIAN SOCIETY OF NEUROGASTROENTEROLOGY WITH ROME IV REGIONAL CENTRAL EAST EUROPEAN MEETING. 2017, p. 200-204.

40. EIFEL, PJ, ROSS, J, HENDRICKSON, M, COX, RS, KEMPSON, R, MARTINEZ, A. Adenocarcinoma of the endometrium. Analysis of 256 cases with disease limited to the uterine corpus: treatment comparisons. Cancer. 52(6), 1983. p.1026-31.

Manuscript received: 4.11 .2019 